\title{
Response of pearl millet (Pennisetum glaucum L.) to plant population in the semi-arid environments of Nigeria
}

\author{
Hakeem Ayinde Ajeigbe ${ }^{1 \star}$, Folorunso Mathew Akinseye ${ }^{1,2}$, Ayuba Kunihya ${ }^{1}$, Abdulsalam \\ Ibrahim Abdullahi ${ }^{3}$ and Alpha Yaya Kamara ${ }^{4}$ \\ ${ }^{1}$ International Crop Research Institute for the Semi-Arid Tropics (ICRISAT), Kano, Nigeria. \\ ${ }^{2}$ Department of Meteorology and Climate Science, Federal University of Technology Akure, Ondo State, Nigeria. \\ ${ }^{3}$ Centre for Dryland Agriculture, Bayero University Kano, Kano, Nigeria. \\ ${ }^{4}$ International Institute of Tropical Agriculture (IITA), Kano, Nigeria.
}

Accepted 14 January, 2019

\begin{abstract}
Low planting densities and use of unimproved varieties contribute to the low yields of pearl millet (Pennisetum glaucum L.) in Nigeria. Field experiments were conducted during the 2013 and 2014 growing seasons, to evaluate the response of pearl millet varieties to varying plant hill population in semi-arid environments of Nigeria. Year, variety and plant hill population had significant $(p \leq 0.05)$ effect on days to $50 \%$ flowering, grain and stalk yields. With exception of Sosat-C88 at 8,889 hills ha ${ }^{-1}$, the grain and stalk yields of pearl millet varieties were found to be significantly higher at higher hill populations than lower hill populations in both locations. Plant chlorophyll content (SPAD) at 21 DAS (days after sowing) was higher and significantly correlated with grain yields in Minjibir than value at 42 DAS. Similarly, leaf area index (LAI) at 42 DAS was significantly correlated with grains than at 63 DAS. Increasing hill population to 13,333, 26,667 and 53,333 hills ha $^{-1}$ increased grain yield by 5.8, 5.3 and $4.5 \%$ in Minjibir and by 14.3, 18.7 and $10.1 \%$ in Gambawa respectively compared to 8,889 hills ha $^{-1}$. Similarly, stalk yields increased with increased plant hill population, which ranged from 6 to $23 \%$ at Minjibir and 11 to $15 \%$ at Gambawa over 8,889 hills ha 1. Sosat-C88 was found to produce higher yield across the different hills population than the other varieties tested with mean yield gained by $17 \%$ in Minjibir and 19.3\% in Gambawa over local variety. Results suggest no blanket recommendation for the hill population across the varieties; GB8765 attained an optimal yield at a population of 13,333 hills ha $^{-1}$ in both locations beyond which grain yield decline. Sosat-C88 produced an optimum yield at lower population of 8,889 hills ha $^{-1}$ at Minjibir and higher population of 26,667 hills ha $^{-1}$ at Gambawa while local variety an optimal yield was stable at 26,667 hills $^{-1}{ }^{-1}$ in both locations.
\end{abstract}

Keywords: Hill populations, leaf area index, productivity, plant chlorophyll, semi-arid tropics.

${ }^{*}$ Corresponding Author: h.ajeigbe@cgiar.org.

\section{INTRODUCTION}

In the semi-arid region of West Africa, $97 \%$ of the agricultural land is rainfed with cereal crops yield of about 500 to $1000 \mathrm{kgha}^{-1}$ (Rockström et al., 2004). In these areas, pearl millet is one of the most reliable cereal crops grown under short duration (4 to 5 months) rainfed condition (Taylor, 2004; Uzoma et al., 2010). It is a drought tolerant, warm-season crop predominantly grown as a staple food grain and a source of feed and fodder (Yadav, 2010; Sathya et al., 2013). Pearl millet is a high quality forage crop in the developed countries like U.S.A and Australia, and considered as a new experimental forage crop in South America and Korea (Khairwal et al., 2007). It is the only cereal that reliably provides grain and fodder under dryland conditions in shallow and sandy 
soils with low fertility and water holding capacity (Andrews and Bramel-Cox, 1993; Wilson et al., 1995). Because of its tolerance to drought, it can be grown in areas where other cereal crops such as maize and sorghum would not survive (Basavaraj et al., 2010) and can yield in areas that receive rainfall as low as 200 to 250 mm (Tabo, 1995; Bidinger and Hash, 2003). In 2009, improved pearl millet varieties accounted for $34.8 \%$ adoption among farmers with a total 1,154,261 ha cultivated across Sudano-Sahelian zone of Nigeria (Ndjeunga et al., 2011). Though, the analysis of longterm (20-year) millet production indicated national average yield of $1170 \mathrm{~kg} \mathrm{ha}^{-1}$ (FAOSTAT, 2016), significant downward yield production (2011 to 2016), indicated most smallholder farmers still produce as low as average yield of $500 \mathrm{kgha}^{-1}$ (Ndjeunga et al., 2011). Hence, modalities to augment or intensify its production will help to increase food security and reduce poverty among the increasing human population in the country.

The present low yield could be attributed not only to variability of water availability related to the erratic rainfall patterns leading to water stress at some critical plantgrowth stages (Chakraborty and Newton, 2011), but also to low inherent soil fertility, lack of use of improved varieties, fertilizer and the use of low plant population (Doumbia et al., 2008). Plant population has a profound effect on yield and yield component of most field crops (Mohammed et al., 2008; Tajul et al., 2013). The plant population is not only in terms of the number of plants per unit area, (i.e. plant density), but also in terms of the arrangement of the plants on the ground. West African pearl millet farmers traditionally plant low plant populations of approximately 5000 hills ha $^{-1}$ ( 2 to 5 plants hill $^{-1}$ ) in order to reduce risk of yield loss from water stress (Bationo et al., 1992) and allows plants to scavenge large soil volumes for the limited nutrients available (Mason et al., 2015). In village surveys conducted in Nigeria, Agber et al. (2012) found that planting density of millet averaged 10,000 hills ha $^{-1}$ with high variability between farmer's fields while some even planted at much lower rates. When land is not limiting and no inputs such as pesticides, or fertilizer are used, low plant density has little effect on the farmer's profit or labour requirement. As the need to raise production per unit of land area increases, fertilizer use and increase plant density are necessary to optimize production in order to gain maximally from the applied input. Numerous trials conducted in West Africa with maize and sorghum have shown that plant density and inter-row spacing have a significant effect on water use, grain yield, and fertilizer use efficiency (Fatondji et al., 2011). Increased plant populations, combined with the use of improved varieties and recommended fertilizer application, have been found to increase pearl millet grain yields. Bationo et al. (1990) found that increasing population from 5000 to 40,000 hills $\mathrm{ha}^{-1}$ increased yields in years with normal and above average rainfall, with only a slight yield decrease in drought years in Niger. Payne (1997) reported that even in dry years, higher grain yield and water use efficiency are possible using a plant population of 20,000 hills ha $^{-1}$ with application of 40 and $18 \mathrm{~kg} \mathrm{P} \mathrm{ha}^{-1}$. In contrast, De Rouw (2004) reported that higher plant populations increased the risk of crop failure. Pearl millet recommendations for plant population and spacing vary with anticipated seasonal rainfall and soil water holding capacity. Some farmers keep low plant populations to enhance intercropped cowpea yield in intercropping systems (Grema and Odo, 1998) but increased pearl millet yields can be produced by plant populations that are two to four times greater than traditionally used (Bationo et al., 1990; Maman et al., 2000a, b).

Though several high yielding millet varieties are available in the sub-region, there is little information on their response to increased plant population given the long term practice of growing millet at very low populations in the region. The objective of this study was to determine the responses of morphologically different pearl millet varieties to varying plant hill population under semi-arid environments of Nigeria.

\section{MATERIALS AND METHODS}

\section{Experimental sites}

The experiments were conducted in two locations during 2013 and 2014 growing seasons in the semi-arid region of Nigeria. The first location was ICRISAT Research field situated within Institute for Agricultural Research in Wasai, Minjibir Local Government Area, Kano State (Latitudes $12.17^{\circ} \mathrm{N}$ and longitude $8.65^{\circ} \mathrm{E}$ ). The second location was ICRISAT Experimental site on a farmer's field at Gambawa, Gumel Local Government Area, Jigawa State (Latitude $12.98^{\circ} \mathrm{N}$ and Longitude $9.75^{\circ} \mathrm{E}$ ). Both sites have a mono-modal rainfall pattern; most of the rain in the area comes as shortduration, high-intensity storms between June and September with one or two rainfall events in October. About $70 \%$ of the total rainfall is received between July and August during the growing season.

\section{Experimental design and treatments}

The experimental design was a split-plot with four (4) replications. Millet varieties were assigned to the main plot while plant populations were assigned to the subplot. In both locations, pearl millet varieties used include two improved (Sosat-C88 and GB8735) and one local (Danmagarawa). Sosat-C88 was developed by ICRISAT and IER. It is a medium maturing variety (90 days), with an average height of $2 \mathrm{~m}$, medium head length (mean of $28 \mathrm{~cm}$ ) with compact head. Sosat-C88 was released by the NCVRC (National Crop Variety Release Committee) in Nigeria in the year 2000. This variety is preferred for its good taste, earliness and high grain yield. It is also preferred for early maturity, insect tolerance, grain colour, cooking time, and head filling. It is the most popular of all the improved varieties released in Nigeria (Ndjeunga et al., 2011).

GB8735 is an early maturing variety (65 to 70 days), with average height of $1.5 \mathrm{~m}$ and short panicle (mean of $22 \mathrm{~cm}$ ). This variety is susceptible to stem borers. It is recommended under rainfall condition between 350 and $600 \mathrm{~mm}$ on sandy and sandy loam soils (Ndjeunga et al., 2011). Local variety was the common Landrace used in the area. Generally, it is preferred for long head and large stalk, and good food quality. It is a medium maturing variety maturing in 70 to 75 days. The sub-plot consisted of the 
population of $8889,13333,26667$ and 53333 hills $\mathrm{ha}^{-1}$ corresponding to intra-row spacing of $150 \mathrm{~m}, 100,50$ and $25 \mathrm{vcm}$ respectively against the standard inter-row spacing of $75 \mathrm{~cm}$. Each subplot occupied 4 rows of $6 \mathrm{~m}$ long $(6 \mathrm{~m} \times 3 \mathrm{~m})$. There was 1 row blank between the sub plots and between the main plots.

\section{Cultural practices}

The land was harrowed and ridged with tractor at Minjibir and ridged with work bulls in Gambawa. The ridges were made $75 \mathrm{~cm}$ apart; the plots were then laid out as per treatments. In the 2013 growing season, the seeds were sown on $3^{\text {rd }}$ June at Minjibir and $25^{\text {th }}$ June at Gambawa while 2014 growing season was planted on the $10^{\text {th }}$ June at Minjibir and $7^{\text {th }}$ July at Gambawa respectively. Six (6) seeds were sown per hole, at a depth of 3 to $4 \mathrm{~cm}$ and later thinned to 2 seedlings per hill 14 days after sowing (DAS). Fertilizer applications were applied in two split doses at the recommended rate of NPK 60:30:30. The first dose was applied at sowing by drilling at $30 \mathrm{~kg} \mathrm{~N}, 30 \mathrm{~kg} \mathrm{P}_{2} \mathrm{O}_{5}, 30 \mathrm{~kg} \mathrm{~K} \mathrm{O}_{2}$ / ha and the second dose of $30 \mathrm{kgN}$ was applied at 6 week after sowing using urea $(46 \% \mathrm{~N})$. Weeding was carried out manually twice at 3 and 6 weeks after sowing.

\section{Data collection}

\section{Soil physio-chemical properties and weather trends during growing seasons}

Prior to sowing in 2013 cropping season, soil was sampled at two profile depth (0 to $15 \mathrm{~cm}$ and 15 to $30 \mathrm{~cm}$ ) and in 2014 cropping season, it was sampled only at 0 to $20 \mathrm{~cm}$ depth. The soil sample was air dried at room temperatures, grind and sieved before being analysed for physio-chemical properties determination. The physical and chemical properties of the soil in the two experimental sites are presented in Table $1 \mathrm{a}$ and $\mathrm{b}$. The soils in the two locations were sandy soil characterized by less than $10 \%$ clay and silt and more than $88 \%$ sand. They were generally acidic with soil $\mathrm{pH}$ range from 5.0 to 6.4 topsoil in Minjibir while that of Gambawa site varied from 5.4 to 6.3. In both seasons (2013 and 2014), Minjibir soil had slightly higher fertility status than Gambawa. It contained higher organic carbon (2.21 and $\left.3.58 \mathrm{gkg}^{-1}\right)$, total $\mathrm{N}(0.232$ and $0.245 \mathrm{gkg}$ $\left.{ }^{1}\right)$ and P-Bray1 $\left(7.8 \mathrm{mgkg}^{-1}\right)$, and $\mathrm{Ca}\left(3.0\right.$ and $\left.2.014 \mathrm{cmol} \mathrm{kg}^{-1}\right)$ in the top soil which was higher than that of Gambawa which contain 1.42 and $2.45 \mathrm{gkg}^{-1}$ of organic carbon, 0.147 and $0.207 \mathrm{gkg}^{-1}$ of total $\mathrm{N}$ and P-Bray1 (4.9 and $\left.5.5 \mathrm{mgkg}^{-1}\right), 2.0$ and $2.288 \mathrm{cmol} \mathrm{kg}^{-1}$ of $\mathrm{Ca}$, respectively. The exchangeable $\mathrm{K}$ in the topsoil was, however, lower at Minjibir $\left(0.223\right.$ and $\left.0.269 \mathrm{cmol}(+) \mathrm{kg}^{-1}\right)$ than in Gambawa $\left(0.379\right.$ and $\left.0.427 \mathrm{cmol}(+) \mathrm{kg}^{-1}\right)$, but the exchangeable $\mathrm{K}$ in the subsoil in Minjibir $\left(0.297 \mathrm{cmol}^{(+)} \mathrm{kg}^{-1}\right)$, was higher than in Gambawa $\left(0.231 \mathrm{cmol}^{(+)} \mathrm{kg}^{-1}\right)$.

Weather data for the trial conducted at Minjibir research station were collected from the ICRISAT Meteorological station adjacent to the experiment plot. Gambawa weather data were obtained from the Jigawa Agricultural and Rural Development Authority (JARDA), Gumel office (about $10 \mathrm{~km}$ from the plot). The meteorological data reported include daily rainfall, minimum temperature, maximum temperature and number of rainy days (NRD). A rainy day was determined as a rain event having received over $0.85 \mathrm{~mm}$ (Omotosho et al., 2000). The monthly distribution and interseasonal trend for both rainfall, number rainy days (NRD) and temperature in both locations indicated high variability (Table 2). Average monthly minimum temperature varied from 21.6 to $26.4^{\circ} \mathrm{C}$ at Minjibir. The average monthly maximum temperature varied from 31.1 to $40.8^{\circ} \mathrm{C}$ at Minjibir. The average monthly minimum temperature in Gambawa ranged from 23.3 to $27.3^{\circ} \mathrm{C}$ and average monthly maximum temperature varied from 33.5 to $40.5^{\circ} \mathrm{C}$ (Table $2 b$ ). Both sites indicate warming throughout the growing season; however, Gambawa was warmer than Minjibir year round.

Table 1a. Soil physio-chemical properties of the experimental site in 2013 cropping season at Minjibir and Gambawa.

\begin{tabular}{|c|c|c|c|c|c|c|c|c|c|c|c|}
\hline Depth & Sand & Silt & Clay & $\mathrm{PH}\left(\mathrm{H}_{2} \mathrm{O}\right)$ & $\begin{array}{l}\text { Organic } \\
\text { carbon }\end{array}$ & Total-N & P-Bray1 & $\mathrm{Ca}$ & $\mathrm{K}$ & $\mathrm{Zn}$ & $\mathrm{Pb}$ \\
\hline $\mathrm{cm}$ & $\%$ & $\%$ & $\%$ & & $\mathbf{g} / \mathbf{k g}$ & g/kg & $\mathrm{mg} / \mathrm{kg}$ & $\mathrm{Cmol}(+) / \mathrm{kg}$ & $\mathrm{Cmol}(+) / \mathrm{kg}$ & $\mathrm{mg} / \mathrm{kg}$ & $\mathrm{mg} / \mathrm{kg}$ \\
\hline \multicolumn{12}{|l|}{ Minjibir } \\
\hline $0-15$ & 91.7 & 4.0 & 4.2 & 5.1 & 2.21 & 0.232 & 7.8 & 3.00 & 0.223 & 0.012 & Traces \\
\hline $15-30$ & 89.8 & 4.2 & 6.0 & 5.0 & 1.55 & 0.181 & 4.6 & 17.79 & 0.297 & Traces & Traces \\
\hline \multicolumn{12}{|c|}{ Gambawa } \\
\hline $0-15$ & 88.9 & 4.6 & 6.5 & 5.4 & 1.42 & 0.147 & 4.9 & 2.00 & 0.379 & Traces & Traces \\
\hline $15-30$ & 92.8 & 4.6 & 2.5 & 5.7 & 1.56 & 0.152 & 4.1 & 1.32 & 0.231 & Traces & Traces \\
\hline
\end{tabular}

\section{Crop measurements: Soil-plant-analysis development (SPAD) and leaf area index (LAI) and number of productive tillers}

SPAD and LAI measurements were randomly taken at three points within the two middle rows in each plot and averaged value was recorded for that plot. The chlorophyll index was measured by the SPAD-502 meter. LAI was measured with an AccuPAR LP-80. Samplings were performed twice during crop growth at 21 DAS and 42 DAS for chlorophyll, and at 42 DAS and 63 DAS for LAI. However, at harvest average number of productive tillers per hill was determined from five (5) randomly selected hills within the net plot area.

\section{Number of days to $50 \%$ flowering and 1000 -seed weight}

The number of days from sowing to the stage when $50 \%$ of the plants in each net plot had flowered was taken and recorded. The number of days from sowing to $95 \%$ maturity was recorded for each net plot. 1000 seeds were counted using Numigral seed counter and then weighed using a 1036SVSSDR Salter sensitive balance.

\section{Grain yield and stalk yield}

Panicles were harvested at physiological maturity stage and sun 
Table 1b. Soil physio-chemical properties of the experimental site in 2014 cropping season at Minjibir and Gambawa.

\begin{tabular}{|c|c|c|c|c|c|c|c|c|c|c|c|}
\hline Depth & Sand & Silt & Clay & $\mathrm{PH}\left(\mathrm{H}_{2} \mathrm{O}\right)$ & Organic carbon & Total-N & P-Bray1 & $\mathrm{Ca}$ & $\mathrm{K}$ & CEC & $\mathrm{Pb}$ \\
\hline $\mathbf{c m}$ & $\%$ & $\%$ & $\%$ & & $\mathrm{~g} / \mathrm{kg}$ & $\mathbf{g} / \mathbf{k g}$ & $\mathrm{mg} / \mathbf{k g}$ & $\mathrm{Cmol}(+) / \mathrm{kg}$ & $\mathrm{Cmol}(+) / \mathrm{kg}$ & $\mathrm{g} / \mathrm{kg}$ & $\mathrm{mg} / \mathrm{kg}$ \\
\hline \multicolumn{12}{|l|}{ Minjibir } \\
\hline $0-20$ & 93.5 & 2.5 & 4.0 & 6.40 & 3.58 & 0.245 & 7.8 & 2.014 & 0.269 & 25.60 & Traces \\
\hline \multicolumn{12}{|c|}{ Gambawa } \\
\hline $0-20$ & 90.8 & 4.3 & 4.9 & 6.32 & 2.45 & 0.207 & 5.5 & 2.288 & 0.427 & 22.53 & Traces \\
\hline
\end{tabular}

Table 2a. Meteorological data of the experimental sites at Minjibir in the 2013 and 2014 growing seasons.

\begin{tabular}{|c|c|c|c|c|c|c|c|c|}
\hline \multirow[b]{2}{*}{ Month } & \multicolumn{4}{|c|}{2013} & \multicolumn{4}{|c|}{2014} \\
\hline & $\begin{array}{c}\text { Rainfall } \\
(\mathrm{mm})\end{array}$ & $\begin{array}{c}\text { Number of } \\
\text { rainy days } \\
\text { (NRD) }\end{array}$ & $\underset{\left({ }^{\circ} \mathrm{C}\right)}{\mathrm{T} \text { min }}$ & $\underset{\left({ }^{\circ} \mathrm{C}\right)}{T_{\max }}$ & $\begin{array}{c}\text { Rainfall } \\
(\mathrm{mm})\end{array}$ & $\begin{array}{c}\text { Number of } \\
\text { rainy days } \\
\text { (NRD) }\end{array}$ & $\underset{\left({ }^{\circ} \mathrm{C}\right)}{\mathrm{T} \min }$ & T_max $\left({ }^{\circ} \mathrm{C}\right.$ \\
\hline Jan & 0 & 0 & 14.2 & 31.7 & 0 & 0 & 15.3 & 31.4 \\
\hline Feb & 0 & 0 & 18.0 & 34.4 & 0 & 0 & 18.4 & 32.9 \\
\hline Mar & 0 & 0 & 19.9 & 41.5 & 0 & 0 & 22.8 & 38.3 \\
\hline Apr & 12.8 & 2 & 25.1 & 39.1 & 36 & 2 & 25.7 & 40.3 \\
\hline May & 33.2 & 1 & 26.4 & 40.8 & 7.7 & 1 & 26.2 & 37.8 \\
\hline Jun & 84.2 & 6 & 22.3 & 30.5 & 69.0 & 5 & 25.1 & 36.6 \\
\hline Jul & 262.4 & 9 & 22.5 & 33.4 & 151.1 & 4 & 23.9 & 32.8 \\
\hline Aug & 522.9 & 13 & 21.6 & 31.1 & 443.4 & 10 & 22.8 & 34.8 \\
\hline Sept & 159.3 & 4 & 22.4 & 34.4 & 135.5 & 5 & 23.1 & 32.4 \\
\hline Oct & 4 & 1 & 22.9 & 36.3 & 20.1 & 2 & 21.7 & 34.3 \\
\hline Nov & 0 & 0 & 15.5 & 35.8 & 0 & 0 & 18.7 & 34.3 \\
\hline Dec & 0 & 0 & 13.6 & 32.3 & 0 & 0 & 15.3 & 30.5 \\
\hline Total/Mean & 1078.5 & 36 & 20.4 & 35.1 & 826 & 29 & 21.6 & 34.7 \\
\hline
\end{tabular}

Source: IITA Minjibir Research Station, Kano.

dried to constant weight. After drying, manual threshing was done to separate grains from shaft. The panicles in the net plots were cut and sun dried to constant weight. The weight recorded as panicle weight per plot. The sun dried panicles were threshed, winnowed and the grains were weighed using Salter sensitive balance with model number 1036SVSSDR. The grain weight per plot was extrapolated to grain yield $\left(\mathrm{kg} \mathrm{ha}^{-1}\right)$. The plants, whose panicles have been harvested, were cut at the ground level. The stalks were left on the field for sun-dried to constant weight, which lasted until twenty days. Thereafter, the stalk weight per plot was extrapolated to the stalk yield $\left(\mathrm{kg} \mathrm{ha}^{-1}\right)$. The stalk and panicle weight, including the grain were given as biomass weight and used in the calculation of harvest index.

\section{Data analysis}

The data collected were subjected to analysis of variance (ANOVA) which was used to determine the effects of different fertilizer application, variety and planting density on the growth, development, yield and yield components parameters using Genstat $15^{\text {th }}$ version. The treatment means that were significantly different at $5 \%$ were compared using Least Significant Difference (LSD). The relationship between the characters evaluated was established at LSD (5\%) probability level using Pearson's correlation coefficient.

\section{RESULTS}

\section{Soil-plant-analysis development (SPAD), leaf area index (LAI) and tillering}

Table 3 shows the effect of pearl millet variety and hill population on SPAD measurement and LAI in both locations. SPAD value increased from high population $\left(53,333\right.$ hills ha $\left.^{-1}\right)$ to low population $\left(8,889\right.$ hills ha $\left.^{-1}\right)$ and varied among the varieties in both locations. At 21 DAS, SPAD differed significantly among the varieties and hill population in Gambawa but significant differences were not observed in Minjibir. However, GB8765 recorded mean SPAD value that was significantly higher than the other varieties in both locations while there were no significant differences between local and Sosat-C88. Hill populations of 8,889 and $13,333 \mathrm{ha}^{-1}$ had mean SPAD values of 55.6 and 57.1 in Minjibir and 51.7 and 50.6 at Gambawa respectively. These were significantly higher 
Table 2b. Meteorological data of the experimental sites at Gambawa in the 2013 and 2014 growing seasons.

\begin{tabular}{|c|c|c|c|c|c|c|c|c|}
\hline \multirow[b]{2}{*}{ Month } & \multicolumn{4}{|c|}{2013} & \multicolumn{4}{|c|}{2014} \\
\hline & $\begin{array}{c}\text { Rainfall } \\
(\mathrm{mm})\end{array}$ & $\begin{array}{l}\text { Number of } \\
\text { rainy days } \\
\text { (NRD) }\end{array}$ & $\frac{\left.{ }^{\top}{ }^{\circ} \mathrm{C}\right)}{\operatorname{Con})}$ & $\underset{\left({ }^{\circ} \mathrm{C}\right)}{\text { T_max }}$ & $\begin{array}{l}\text { Rainfall } \\
(\mathrm{mm})\end{array}$ & $\begin{array}{l}\text { Number of } \\
\text { rainy days } \\
\text { (NRD) }\end{array}$ & $\underset{\left({ }^{\circ} \mathrm{C}\right)}{\mathrm{T} \min }$ & $\underset{\left({ }^{\circ} \mathrm{C}\right)}{\mathrm{T}_{\max }}$ \\
\hline Jan & 0 & 0 & 16.6 & 33.1 & 0 & 0 & 14.7 & 33.0 \\
\hline Feb & 0 & 0 & 18.4 & 36.2 & 0 & 0 & 17.9 & 34.9 \\
\hline Mar & 0 & 0 & 22.4 & 40.6 & 0 & 0 & 22.0 & 38.8 \\
\hline Apr & 0 & 0 & 24.8 & 40.1 & 0 & 0 & 26.2 & 41.3 \\
\hline May & 7 & 4 & 26.6 & 41.4 & 0 & 4 & 26.8 & 40.5 \\
\hline Jun & 133 & 7 & 26.8 & 39.6 & 64 & 11 & 27.3 & 40.3 \\
\hline Jul & 153 & 16 & 25.3 & 36.5 & 268 & 9 & 26.0 & 37.0 \\
\hline Aug & 187 & 19 & 23.3 & 33.8 & 432 & 14 & 23.0 & 33.5 \\
\hline Sept & 70 & 9 & 24.0 & 37.1 & 193 & 12 & 22.9 & 35.4 \\
\hline Oct & 0 & 1 & 22.8 & 38.0 & 30 & 2 & 22.4 & 37.7 \\
\hline Nov & 0 & 0 & 19.2 & 36.9 & 0 & 0 & 19.0 & 36.1 \\
\hline Dec & 0 & 0 & 16.8 & 33.3 & 0 & 0 & 14.6 & 32.2 \\
\hline Total/Mean & 550 & 56 & 22.3 & 37.2 & 986.5 & 52 & 21.9 & 36.7 \\
\hline
\end{tabular}

Source: JARDA office, Jigawa.

Table 3. Effect of pearl millet varieties and hill population density on soil-plant-analysis development (SPAD) leaf area index (LAI) and tillering in in both locations.

\begin{tabular}{|c|c|c|c|c|c|c|c|c|c|c|}
\hline \multirow[b]{2}{*}{ Treatments } & \multicolumn{5}{|c|}{ Minjibir } & \multicolumn{5}{|c|}{ Gambawa } \\
\hline & $\begin{array}{c}\text { SPAD } \\
\text { (21DAS) }\end{array}$ & $\begin{array}{c}\text { SPAD } \\
\text { (42DAS) }\end{array}$ & $\begin{array}{c}\text { LAI } \\
\text { (42DAS) }\end{array}$ & $\begin{array}{c}\text { LAI } \\
\text { (63DAS) }\end{array}$ & $\begin{array}{c}\text { \#Tiller/ } \\
\text { hill }\end{array}$ & $\begin{array}{c}\text { SPAD } \\
\text { (21DAS) }\end{array}$ & $\begin{array}{c}\text { SPAD } \\
\text { (42DAS) }\end{array}$ & $\begin{array}{c}\text { LAI } \\
\text { (42DAS) }\end{array}$ & $\begin{array}{c}\text { LAI } \\
\text { (63DAS) }\end{array}$ & $\begin{array}{c}\text { \#Tillel } \\
\text { /hill }\end{array}$ \\
\hline \multicolumn{11}{|l|}{ Variety (V) } \\
\hline GB8765 & 56.04 & 49.31 & 2.21 & 2.36 & 2.69 & 51.74 & 49.15 & 2.19 & 2.07 & 2.77 \\
\hline Sosat-C88 & 53.04 & 42.86 & 2.68 & 2.59 & 2.33 & 46.23 & 47.91 & 2.75 & 2.36 & 2.3 \\
\hline Local & 55.24 & 49.64 & 2.40 & 2.41 & 2.86 & 49.23 & 46.15 & 2.42 & 2.6 & 2.47 \\
\hline$P$ of $F$ & 0.403 & 0.041 & 0.028 & 0.287 & 0.314 & 0.037 & 0.6 & 0.052 & 0.099 & 0.026 \\
\hline SED & 2.135 & 2.27 & 0.129 & 0.141 & 0.325 & 2.008 & 2.852 & 0.176 & 0.2 & 0.127 \\
\hline LSD & 5.224 & 5.555 & 0.315 & 0.346 & 0.794 & 3.912 & 6.979 & 0.43 & 0.49 & 0.31 \\
\hline \multicolumn{11}{|c|}{ Hill population $\left(\right.$ ha $\left.^{-1}\right)$} \\
\hline 8889 & 55.63 & 50.85 & 2.7 & 2.46 & 3.24 & 51.7 & 51.33 & 2.53 & 2.42 & 3.35 \\
\hline 13333 & 57.05 & 49.44 & 2.65 & 2.41 & 3.79 & 50.59 & 50.2 & 2.51 & 2.51 & 3.03 \\
\hline 26667 & 54.40 & 44.33 & 2.1 & 2.46 & 1.85 & 47.82 & 44.83 & 2.55 & 2.23 & 1.98 \\
\hline 53333 & 52.02 & 44.44 & 2.25 & 2.47 & 1.61 & 46.17 & 44.58 & 2.23 & 2.23 & 1.68 \\
\hline$P$ of $F$ & 0.145 & $<.001$ & 0.015 & 0.992 & $<.001$ & 0.019 & 0.03 & 0.228 & 0.447 & $<.001$ \\
\hline SED & 2.157 & 1.655 & 0.206 & 0.206 & 0.286 & 1.81 & 2.681 & 0.172 & 0.209 & 0.212 \\
\hline LSD & 4.427 & 3.395 & 0.422 & 0.282 & 0.587 & 3.714 & 5.501 & 0.354 & 0.43 & 0.435 \\
\hline Mean & 54.77 & 47.27 & 2.43 & 0.423 & 2.62 & 49.07 & 47.74 & 2.45 & 2.35 & 2.51 \\
\hline CV & 9.6 & 8.6 & 20.8 & 20.6 & 26.7 & 9 & 13.8 & 17.2 & 21.9 & 20.6 \\
\hline$V^{*} P$ & ns & ns & ns & $\mathrm{ns}$ & $* *$ & ns & * & ns & ns & ns \\
\hline
\end{tabular}

than populations of 26,667 and 53,333 hills ha ${ }^{-1}$ in Minjibir (54.4 and 42.0) and Gambawa (47.8 and 46.2) respectively. Similarly, significant differences were found among varieties and hill populations for SPAD values at 42 DAS in both locations.
Significant differences were observed among the pearl millet varieties and hill population for mean LAl at 42 DAS in both locations except for hill population at Gambawa. In contrast, were no significant differences among the millet varieties and hill population for mean LAI at 63 DAS 
in both locations. Although, there were no significant differences in mean LAI across the hill population at both locations at 63 DAS, significant differences were observed at 42 DAS at Minjibir. The low hill population of 8,889 hills $^{-1} \mathrm{ha}^{-}$had significantly higher LAl in Minjibir and Gambawa.

Similarly, significant differences were observed among millet varieties and among plant hill population for tillering. in Gambawa GB8765 (2.77/hill) produced significantly higher number of tillers than the local (2.47/hill) and Sosat-C88 (2.3/hill) millet varieties Gambawa,. However, there were no significant differences among the pearl millet varieties for tillering in Minjibir. The lower hill population produced significantly higher number of tillers than the higher plant hill populations in both locations. In Minjibir, mean number of tillers range from $1.61 /$ hill $\left(53,333\right.$ hills $\left.\mathrm{ha}^{-1}\right)$ to 3.79 tiller/hill $\left(13,333\right.$ hills ha $\left.^{-1}\right)$, while in Gambawa it ranged \left. from $1.68{\text { tillers } \text { hill }^{-1}(53,333 \text { hills ha }}^{-1}\right)$ to 3.35 tillers hill $^{-1}$ $\left(8,889\right.$ hills $\left.\mathrm{ha}^{-1}\right)$. In general, there was no significance interaction between variety and hill population across the parameters except for the number of tiller/hill at Minjibir and SPAD value at 42 DAS in Gambawa.

\section{Days to $50 \%$ flowering, thousand seed weight (1000- sw), grain and stalk yields}

Significantly differences were observed between the year for $50 \%$ days, 1000 -sw, grain and stalk yields of pearl millet at both locations except for 1000-sw in Minjibir (Table 4). The hill population (HP) had significant effect on days to $50 \%$ flowering, 1000 -sw and stalk yield in Minjibir while only 1000-sw and grain yields were significantly affected in Gambawa (Table 4). Significant differences were also observed among the millet varietal (V) for all traits measured except for 1000-sw in both locations. Meanwhile, the interaction between the hill population and variety $(\mathrm{HP} \times \mathrm{V})$ was significant for days to $50 \%$ flowering and grain yield in Minjibir while only stalk yield was significant in Gambawa. Table 4 also shows that there are no interaction of year, hill population and variety $(\mathrm{Y} \times \mathrm{HP} \times \mathrm{V})$ in both locations.

In Minjibir, 2013, the millet flowered at a mean of 56 DAS, this was significantly earlier than 61 DAS for $50 \%$ flowering in 2014. In contrast, at Gambawa, millet flowered at 64 DAS in 2013 indicating 4-day delay compared to 2014 (Table 5). Although, there was no significant difference between the years for 1000-seed weight at Minjibir, in Gambawa the mean 1000-seed weight in 2014 was significantly higher than in 2013. The mean yields recorded were higher in Minjibir than Gambawa in both seasons (Table 5). While, mean grain yields recorded in the 2014 cropping season were significantly higher than the mean grain yields in 2013 cropping season. Minjibir mean stalk yields, in 2013 (9471 $\mathrm{kg} \mathrm{ha}^{-1}$ ) was significantly higher than mean stalk yields in $2014\left(6385 \mathrm{~kg} \mathrm{ha}^{-1}\right)$, while contrast were observed in Gambawa where mean stalk yield in 2013 (3934 kg ha ${ }^{-1}$ ) was significantly lower than mean stalk yield (4934 $\mathrm{kg} \mathrm{ha}^{-1}$ ) in 2014 cropping season.

Plant hill population had no significant effect on number of days to $50 \%$ flowering in both location (Table 6). However significant differences were observed among the millet varieties. Sosat-C88 recorded the highest number of days to flowering at 63 days while the least value of 52 days was observed by GB8765. In Gambawa, the local variety recorded the mean value of 65 days to flowered indicating much longer vegetative growth compared to other varieties while the GB8765 recorded mean lowest value of 50 days to flowering. The results further showed that higher pearl millet hill population recorded significantly lower mean 1000-sw in both locations (Table 6). GB8765 recorded the highest mean 1000 -sw of 11.3 and $8.2 \mathrm{~g}$ per 1000-sw in Minjibir and Gambawa respectively, while the least mean value (10.4 and $7.5 \mathrm{~g}$ per 1000 -sw) was recorded by Sosat-C88 in Minjibir and Gambawa, respectively.

Sosat-C88 produced the highest mean grain yield (3169 and $2169 \mathrm{~kg} \mathrm{ha}^{-1}$ ) while GB8765 produced the least grain yield (2168 and $1573 \mathrm{~kg} \mathrm{ha}^{-1}$ ) in Minjibir and Gambawa (Table 7). Significant population by variety interactions were observed for grain yields in Minjibir. The highest yield of GB8765 was obtained at a population of 13,333 hills ha ${ }^{-1}$ but yield decline with further increase in hill population. Sosat-C88 produced the highest yield at low population of 8,889 hills ha $^{-1}$ in Minjibir and 26,667 hills ha $^{-1}$ in Gambawa. The local variety recorded its lowest mean grain yields at hill population of 13,333 hills ha $^{-1}$ in Minjibir and 8,889 hills ha ${ }^{-1}$ in Gambawa, while its highest yields were obtained at higher population 26,667 hills ha $^{-1}$ in both locations. There were no significant differences among the hill population treatments for millet grain yields in Minjibir, though the differences were significant in Gambawa where the highest mean grain yield of $1962 \mathrm{~kg} \mathrm{ha}^{-1}$ was recorded at hill population of 26,667 hills ha $^{-1}$. Although, there were no significant differences observed among the hill population for stalk yield at Gambawa, highly significant differences were observed at Minjibir. The highest plant hill population $\left(53,333 \mathrm{ha}^{-1}\right)$ produced the highest stalk mean yields (Table 7). Also significant differences were observed among the millet varieties for stalk yields in about locations, as well as significant hill population by Variety interactions in Gambawa. GB8765 produced significant lower mean stalk yields under all treatments.

\section{Growth parameters and yield components association with grain yield}

Table 8 shows the correlation coefficients among millet growth parameters and grain yields in both locations. LAI at 42 DAS and Stalk yield were significantly and 
Table 4. F-probability values for the ANOVA of both the observed and measured parameters of pearl millet varieties at varying hill population in both locations.

\begin{tabular}{|c|c|c|c|c|}
\hline Effect & $50 \%$ Flowering (days) & 1000-seed weight (g) & Grain $\left(\mathrm{kgha}^{-1}\right)$ & Stalk $\left(\mathrm{kgha}^{-1}\right)$ \\
\hline \multicolumn{5}{|l|}{ Minjibir } \\
\hline Year $(\mathrm{Y})$ & $<.001$ & 0.799 & 0.032 & $<.001$ \\
\hline Hill Population(HP) & 0.031 & 0.001 & 0.327 & $<.001$ \\
\hline $\mathrm{Y} \times \mathrm{HP}$ & 0.664 & 0.030 & 0.295 & 0.008 \\
\hline Variety(V) & $<.001$ & 0.131 & $<.001$ & $<.001$ \\
\hline $\mathrm{Y} \times \mathrm{V}$ & 0.161 & 0.003 & $<.001$ & 0.031 \\
\hline $\mathrm{HP} \times \mathrm{V}$ & 0.040 & 0.964 & $<.001$ & 0.077 \\
\hline $\mathrm{Y} \times \mathrm{HP} \times \mathrm{V}$ & 0.803 & 0.215 & 0.629 & 0.696 \\
\hline \multicolumn{5}{|l|}{ Gambawa } \\
\hline Year $(Y)$ & $<.001$ & $<.001$ & $<.001$ & $<.001$ \\
\hline Hill Population(HP) & 0.185 & 0.045 & 0.022 & 0.141 \\
\hline $\mathrm{Y} \times \mathrm{HP}$ & 0.699 & 0.817 & 0.005 & 0.049 \\
\hline Variety(V) & $<.001$ & 0.607 & 0.012 & 0.011 \\
\hline$Y \times V$ & 0.746 & 0.551 & 0.505 & 0.208 \\
\hline $\mathrm{HP} \times \mathrm{V}$ & 0.088 & 0.552 & 0.544 & 0.004 \\
\hline $\mathrm{Y} \times \mathrm{HP} \times \mathrm{V}$ & 0.931 & 0.613 & 0.115 & 0.146 \\
\hline
\end{tabular}

Table 5. Year effects on agronomic parameters of pearl millet in Minjibir and Gambawa.

\begin{tabular}{|c|c|c|c|c|}
\hline Effect & $50 \%$ Flowering (days) & 1000 -seed weight (g) & Grain yield $\left(\mathrm{kgha}^{-1}\right)$ & Stalk yield $\left(\mathrm{kgha}^{-1}\right)$ \\
\hline \multicolumn{5}{|l|}{ Minjibir } \\
\hline \multicolumn{5}{|l|}{ Year } \\
\hline 2013 & 55.9 & 10.79 & 2563 & 9471 \\
\hline 2014 & 60.5 & 10.74 & 2750 & 6385 \\
\hline SED* & $0.55^{\star \star}$ & $0.22^{\mathrm{ns}}$ & $83.8^{*}$ & $302^{* \star}$ \\
\hline \multicolumn{5}{|c|}{ Gambawa } \\
\hline 2013 & 64.2 & 6.91 & 1383 & 3934 \\
\hline 2014 & 60.1 & 8.79 & 2277 & 4934 \\
\hline SED* & $0.73^{* *}$ & $0.41^{* *}$ & $58.1^{* *}$ & $208^{* *}$ \\
\hline
\end{tabular}

positively associated with grain yield in both locations. In addition, SPAD at 21 DAS and $50 \%$ flowering were significantly and positively correlated $\left(0.22^{*}\right.$ and $\left.0.61^{* *}\right)$ with grain yield in Minjibir while non-significant correction with grain yield was observed in Gambawa. In contrast, 1000 -sw and harvest index showed highly significant and positive correction $\left(0.32^{\star *}\right.$ and $\left.0.38^{\star *}\right)$ with grain yield in Gambawa but no significant correlation was observed at Minjibir.

\section{DISCUSSION}

The selected locations for the trial had varied soil and rainfall distributions which provided contrasting environments which represent the semi-arid region of Nigeria. The two locations had sandy-loamy soils and the major soil micro-nutrients varied from low to very low contents. However, Gambawa had lower content of most nutrients than Minjibir, with lower organic carbon, total $\mathrm{N}$, total $\mathrm{P}$ and $\mathrm{Ca}$ in the top soil. Rainfall was higher in amount and intensity in Minjibir than Gambawa. The higher soil fertility status and rainfall recorded in Minjibir compared to Gambawa was reflected in higher grain and stalk yields as well as observed responses of the millet to some treatments in Minjibir. The lower 1000-seed weight measured in Gambawa compared to Minjibir could be attributed to water stress most especially during grain filling, resulting from the erratic rainfall distribution at the site. This is in agreement with Do and Winkel (1993) who found that water stress, decrease pearl millet yields by 14 and $40 \%$ depending on the variety and amount of stress.

Climatic conditions as well as inherent soil fertility can be attributed to variations in response of hill population 
Table 6. $50 \%$ Flowering and 1000-seed weight of pearl millet varieties as influenced by hill population in both locations.

\begin{tabular}{|c|c|c|c|c|c|c|c|c|c|c|}
\hline \multirow[t]{3}{*}{ Variety } & \multicolumn{5}{|c|}{ Minjibir } & \multicolumn{5}{|c|}{ Gambawa } \\
\hline & \multicolumn{10}{|c|}{ Hill population $\left(\mathrm{ha}^{-1}\right)$} \\
\hline & 8889 & 13333 & 26667 & 53333 & Mean & 8889 & 13333 & 26667 & 53333 & Mean \\
\hline & \multicolumn{10}{|c|}{$50 \%$ flowering } \\
\hline GB8765 & 51.6 & 53.4 & 50.9 & 52.3 & 52.0 & 49.9 & 48.9 & 50.4 & 50.4 & 49.9 \\
\hline Sosat-C88 & 63.4 & 61.6 & 63.3 & 64.1 & 63.1 & 59.3 & 60.1 & 58.6 & 59.1 & 59.3 \\
\hline Local & 59.3 & 58.9 & 58.9 & 61.4 & 59.6 & 63.5 & 64.5 & 64.9 & 66.8 & 64.9 \\
\hline Mean & 58.1 & 58.0 & 57.7 & 59.3 & & 57.5 & 57.8 & 58.0 & 58.8 & \\
\hline SED (HP) & $0.53^{*}$ & & & & & $0.56 n s$ & & & & \\
\hline SED (V) & $1.02^{\star *}$ & & & & & $1.52^{\star *}$ & & & & \\
\hline SED (HPXV) & $1.29^{*}$ & & & & & $1.23 \mathrm{~ns}$ & & & & \\
\hline \multirow[t]{2}{*}{ SED (HPXV) } & $0.38^{* *}$ & & & & & $0.24^{\mathrm{ns}}$ & & & & \\
\hline & \multicolumn{10}{|c|}{ 1000-seed weight (g) } \\
\hline GB8765 & 11.7 & 11.9 & 11.2 & 10.5 & 11.3 & 8.4 & 8.2 & 9.0 & 7.1 & 8.2 \\
\hline Sosat-C88 & 11.0 & 10.7 & 10.0 & 9.9 & 10.4 & 8.6 & 7.3 & 7.9 & 6.4 & 7.5 \\
\hline Local & 11.0 & 10.8 & 10.6 & 9.7 & 10.5 & 8.4 & 8.3 & 7.0 & 7.6 & 7.8 \\
\hline Mean & 11.2 & 11.1 & 10.6 & 10.0 & & 8.5 & 8.0 & 8.0 & 7.0 & \\
\hline SED (HP) & $0.29^{* *}$ & & & & & $0.56^{*}$ & & & & \\
\hline SED $(V)$ & $0.39^{\text {ns }}$ & & & & & $0.61^{\mathrm{ns}}$ & & & & \\
\hline SED (HPxV) & $0.59^{\text {ns }}$ & & & & & $1.04^{\mathrm{ns}}$ & & & & \\
\hline
\end{tabular}

Table 7. Grain and stalk yields of pearl millet varieties as influenced by hill population in both locations.

\begin{tabular}{|c|c|c|c|c|c|c|c|c|c|c|}
\hline \multirow[t]{3}{*}{ Variety } & \multicolumn{5}{|c|}{ Minjibir } & \multicolumn{5}{|c|}{ Gambawa } \\
\hline & \multicolumn{10}{|c|}{ Hill population $\left(\mathrm{ha}^{-1}\right)$} \\
\hline & 8889 & 13333 & 26667 & 53333 & Mean & 8889 & 13333 & 26667 & 53333 & Mean \\
\hline & \multicolumn{10}{|c|}{ Grain yield $\left(\mathrm{kgha}^{-1}\right)$} \\
\hline GB8765 & 1706 & 2600 & 2227 & 2137 & 2168 & 1453 & 1746 & 1550 & 1541 & 1573 \\
\hline Sosat-C88 & 3362 & 3044 & 3047 & 3221 & 3169 & 1913 & 2156 & 2420 & 2185 & 2169 \\
\hline Local & 2621 & 2492 & 2746 & 2677 & 2634 & 1594 & 1765 & 1917 & 1722 & 1750 \\
\hline Mean & 2563 & 2712 & 2673 & 2678 & & 1653 & 1889 & 1962 & 1816 & \\
\hline SED (HP) & $83^{\text {ns }}$ & & & & & $96^{*}$ & & & & \\
\hline SED (V) & $132^{\star *}$ & & & & & $135^{\star}$ & & & & \\
\hline \multirow[t]{2}{*}{ SED $(H P \times V)$} & $274^{* *}$ & & & & & $198^{\text {ns }}$ & & & & \\
\hline & \multicolumn{10}{|c|}{ Stalk yield $\left(\mathrm{kgha}^{-1}\right)$} \\
\hline GB8765 & 3631 & 5140 & 5323 & 5927 & 5005 & 2798 & 4246 & 2910 & 3048 & 3251 \\
\hline Sosat-C88 & 10390 & 9348 & 10062 & 10458 & 10065 & 4865 & 5010 & 5660 & 5490 & 5256 \\
\hline Local & 7448 & 8229 & 9198 & 9983 & 8715 & 4458 & 5240 & 5108 & 5375 & 5045 \\
\hline Mean & 7156 & 7572 & 8194 & 8789 & & 4040 & 4832 & 4559 & 4638 & \\
\hline SED (HP) & $372^{\star *}$ & & & & & $272 n s$ & & & & \\
\hline $\operatorname{SED}(\mathrm{V})$ & $471^{\star \star}$ & & & & & $446^{*}$ & & & & \\
\hline SED $(H P \times V)$ & $516^{\text {ns }}$ & & & & & $605^{* *}$ & & & & \\
\hline
\end{tabular}

and varieties on the growth and phenological development (e.g. SPAD, LAI, days to $50 \%$ flowering).
While the pearl millet plants flowered earlier in 2013, the number of days to flowering was the same as in 2014 
Table 8. Correlation analysis of grain yield with growth parameters and yield components of sorghum in Minjibir and Gambawa.

\begin{tabular}{lccccc}
\hline \multirow{2}{*}{ Character } & \multicolumn{2}{c}{ Minjibir } & & \multicolumn{2}{c}{ Gambawa } \\
\cline { 2 - 3 } \cline { 5 - 6 } & $\mathbf{R}$ & P-value & & $\mathbf{R}$ & P-value \\
\hline SPAD (21 DAS) & 0.221 & 0.033 & & 0.042 & 0.194 \\
SPAD (42 DAS) & 0.052 & 0.725 & & 0.092 & 0.133 \\
LAI (42 DAS) & 0.239 & 0.051 & & 0.316 & 0.009 \\
LAI (63 DAS) & 0.037 & 0.802 & & 0.128 & 0.096 \\
50\% flowering (days) & 0.608 & $<.0001$ & & -0.044 & 0.446 \\
\#Tiller/hill $_{\text {1000-seed weight }}^{0.010}$ & -0.074 & 0.948 & & 0.219 & 0.135 \\
Stalk yield (kgha & -1 & 0.471 & & 0.326 & 0.001 \\
Harvest index (\%) & 0.424 & 0.001 & & 0.551 & $<.0001$ \\
& 0.134 & 0.194 & & 0.384 & $<.001$ \\
\hline
\end{tabular}

cropping season. Also, slight delay in flowering occurs at higher hill population than lower population in Minjibir when compared to Gambawa. The level of significant interactions between the hill population and variety of days to $50 \%$ flowering suggests that pearl millet varieties responded to population differently in both locations. This may depend on the environment, especially rainfall distribution and soil fertility. To further confirm the impacts of variability in the growing season on pearl millet, the results indicated that grain yields in 2014 were higher by a mean of $7 \%$ in Minjibir and $65 \%$ higher in Gambawa than 2013 cropping season. However, stalk yields were higher by a mean of 48 and $26 \%$ in 2013 than 2014 in Minjibir and higher by 25\% in 2014 than 2013 in Gambawa.

The recommended plant spacing for millet is $0.75 \times 0.5$ $\mathrm{m}$ providing population of $26,666 \mathrm{ha}^{-1}$ (ICRISAT, 2006) while farmer traditionally plant millet in inter-crop at 1.5 to $2 \mathrm{~m}$ between rows and 1 within rows, this gives a population of 6,667 to 8,889 hills ha $^{-1}$. In the present study, higher hill populations of $13,333(0.75 \times 1 \mathrm{~m})$, $26,667(0.75 \times 0.5 \mathrm{~m})$ and $53,333(0.75 \times 0.25 \mathrm{~m})$ had an average yield increase (5.8, 4.3 and $4.5 \%$ in Minjibir) and (14, 19 and $10 \%$ in Gambawa) compared to a population of 8,889 hills ha ${ }^{-1}(0.75 \times 1.5 \mathrm{~m})$ while stalk yield significantly increased with increase plant hill population. This agrees with Mason et al. (2015) who reported that, increase plant population, combined with the use of improved varieties and recommended fertilizer application increased pearl millet grain yields. Higher grain and stalk yields observed in some treatments at closer spacing across locations indicated the risk in making blanket recommendation on hill population on the varieties. GB8765 produced optimum yield at a population of 13,333 hills ha $^{-1}$ beyond which grain yield decline in both locations. Sosat-C88 produced optimal grain yield at low population of 8,889 hills $^{-1}$ at Minjibir but the optimum yield was produced at a population of 26,667 hills ha ${ }^{-1}$ in Gambawa. The optimum yield at low population $\left(8,889\right.$ hills ha $\left.^{-1}\right)$ at Minjibir can be attributed to early plant vigour resulting to more tillers due to higher soil micro-nutrients compared to Gambawa. Local variety produced an optimum grain yield at a population of 26,667 hills ha ${ }^{-1}$ in both locations. This result agreed closely with the finding by Maman et al., (2000a) which was cited by Mason et al. (2015) that even in a dry year in Niger, higher grain yield and water use efficiency are possible with higher plant populations of 20,000 hills ha $^{-1}$ with application of $40 \mathrm{~kg} \mathrm{~N} \mathrm{ha}^{-1}$ and $18 \mathrm{~kg} \mathrm{P} \mathrm{ha}^{-1}$. In contrast, De Rouw (2004) reported that higher plant populations increased the risk of crop failure. In Minjibir, across the hill population, GB8765 produced grain and stalk yields that were lower by 26.5 and $46.4 \%$ than those produced by Sosat-C88 and local variety, respectively. Sosat-C88 had 24.2 and $31.8 \%$ higher grain yield stalk yields than other varieties. Similar results were found in Gambawa, where GB8765 recorded 19.3 and 47\% grain and stalk yield decreased compared to other varieties, while Sosat-C88 had $23.4 \%$ higher grain yield and $21 \%$ stalk yield than other varieties. Sosat-C88 is therefore a preferred variety among the varieties tested for the semiarid of Nigeria under the normal planting window.

In Minjibir, it was observed that grain yields were significant and positively correlated with SPAD at 21 DAS, LAI at 42 DAS, 50\% flowering and stalk yields. In Gambawa LAI at 42 DAS was significantly and positively correlated with grain yield. This indicates that these traits are very important for the growth and yield of pearl millet. Management practices such as selection of appropriate varieties and plant population, which improves LAI, and leaf greenness are therefore recommended.

\section{Conclusion}

There was a significant response by pearl millet varieties to varying hill populations across locations. Variation in grain yield across locations is attributed to varying in amounts of rainfall received and soil fertility. Sosat-C88 yielded higher than other varieties across the varying 
population in both locations. Based on plant populations, GB8765, Sosat-C88, and Local variety had better on performances at plant population of 13,333, 8,889 and 26,667 hills ha $^{-1}$, respectively. Contrary to widely used population of 8,889 or 13,333 hills ha ${ }^{-1}$ by farmers for pearl millet productivity in the semi-arid of Nigeria, the optimal yield measured in these two growing seasons suggests that population recommendations for pearl millet should vary by variety and environmental conditions. Thus, for GB8765 we recommend a population of 13,333 hills ha $^{-1}$ beyond which grain yield may decline. Sosat-C88 should be planted at low population of 8,889 hills ha $^{-1}$ in a more fertile area and good rainfall pattern, but increased population of 26,667 hills ha ${ }^{-1}$ in a drier and less fertile area while the Local variety should be planted at a population of 26,667 hills $\mathrm{ha}^{-1}$ in the two locations

\section{ACKNOWLEDGEMENT}

The authors would like to thank ICRISAT for providing institutional support for the study. The experiment was conducted under the CG research Program- Grain Legume and Dryland Cereals (GLDC).

\section{REFERENCES}

Agber PI, Ter S, Ayuba SA, 2012. Assessment of pearl millet performance to early and late planting opportunities and fertilizer application models in Makurdi, Nigeria. Afr J Agric Res, 7(44): 59555961.

Andrews DJ, Bramel-Cox $\mathrm{P}, 1993$. Breeding cultivars for sustainable crop production in low-input dryland agriculture in the tropics. In: Buxton DR, Shibles R, Forsberg RA, Blad BL, Asay KH, Paulsen GM, Wilson, RF (eds), International Crop Science 1. Madison, Wisconsin, USA: Crop Science Society of America, 211-222.

Basavaraj G, Rao PP, Bhagavatula S, Ahmed W, 2010. Availability and utilization of pearl millet in India. SAT e-Journal, 8: 1-6.

Bationo A, Christianson CB, Baethgen WE, 1990. Plant density and nitrogen fertilizer effects on pearl millet production in Niger. Agron $\mathrm{J}$, 82: 290-295.

Bationo A, Christianson CB, Baethgen WE, Mokwunye AU, 1992. A farm-level evaluation of nitrogen and $P$ fertilizer use and planting density for pearl millet production in Niger. Fertilizer Res, 31: 175184.

Bidinger FR, Hash CT, 2003. Pearl millet In Nguyen, H. T. (ed). Integration of Physiology and Molecular Biology in Plant Breeding, N.Y, U.S.A: Marcel- Decker.

Chakraborty S, Newton AC, 2011. Climate change, plant diseases and food security: an overview. Plant Pathol, 60: 2-14.

De Rouw, A. (2004). Improving yields and reducing risks in pearl millet farming in the African Sahel. Agric Syst, 81: 73-93.

Do $F$, Winkel $T$, 1993. Morpho-physiologie de la résistance à la sécheresse. In: Hamon, S. (Ed.), Le mil en Afrique. Diversité génétique et agro-physiologie: potentialités et contraintes pour l'amélioration et la culture. Éditions Orstom, pp. 187-204.

Doumbia M, Jarju A, Sene M, Traore K, Yost R, Kablan R, Brannan K, Berthe A, Yamoah C, Querido A, Traoré PCS, Ballo A, 2008. Sequestration of organic carbon in West African soils by Aménagement en Courbes de Niveau. Agron Sust Dev, 29: 267-75.

FAOSTAT (2016). Food and agriculture organization of the United Nations, FAOSTAT database. http://faostat.fao.org/site/362/Desktop Defaultaspx?PagelD=362.
Fatondji D, Hersmann TM, Ajeigbe, HA, Hamidou F, 2011. Integrated genetic and nutrient management options to raise pearl millet productivity under small holder farmer conditions for food sufficiency. ICRISAT Paper presentation.

Grema AK, Odo PE, 1998. Management practices for increasing and stabilizing pearl millet production in Nigeria. In Pearl Millet in Nigerian Agriculture, 76-86 (Eds A. M. Emechebe, M. C. Ikwelle, O. Ajayi, M. Aminu-Kano and A. B. Anaso). Maiduguri, Nigeria: Ramadan Press.

ICRISAT (International Crop Research Institute for Semi-Arid Tropics), 2006. Pear Millet. Available online at www.icrisat.org Retrieved July 17-2009, 7pp.

Khairwal IS, Yadav SK, Rai KN, Upadhyaya HD, Kachhawa D, Nirwan B, Bhattacharjee R, Rajpurohit BS, Dangaria CJ, 2007. Evaluation and identification of promising pearl millet germplasm for grain and fodder traits. J Sat Agric Res, 5(1): 1-6.

Maman N, Mason SC, Sirifi S, 2000a. Influence of variety and management level on pearl millet production in Niger. I. Grain yield and dry matter accumulation. Afr Crop Sci J, 8: 25-34.

Maman N, Mason SC, Sirifi S, 2000b. Influence of variety and management level on pearl millet production in Niger. II. $\mathrm{N}$ and $\mathrm{P}$ concentration and accumulation. Afr Crop Sci J, 8: 35-47.

Mason SC, Maman N, Palé S, 2015. Pearl millet production practices in semi-arid West Africa: A review. Expl Agric. Cambridge University Press.

Mohammed IB, Miko S, Gwaram MY, 2008. Plant population dynamics in field crops: A review. JMST, 1(5): 100-106.

Ndjeunga J, Umar J, Ahmed B, Aba A, Ibro A, Abdoulaye A, Gwadi K, 2011. Adoption and impacts of modern sorghum and pearl millet varieties in Northern Nigeria, ICRISAT.

Omotosho JB, Balogun AA, Ogunjobi K, 2000. Predicting monthly and seasonal rainfall, onset and cessation of the rainy season in West Africa using only surface data. Int J Climatol, 20: 865-880.

Payne WA, 1997. Managing yield and water use of pearl millet. Agron J, 89: 481-490.

Rockström J, Folke C, Gordon L, Hatibu N, Jewitt G, Penning De Vries F, Rwehumbiza F, Sally H, Savenije H, Schulze R, 2004. A watershed approach to upgrade rain-fed agriculture in water scarce regions through water system innovations: an integrated research initiative on water for food and rural livelihoods in balance with ecosystem functions. Phys Chem Earth, 29: 1109-1118.

Sathya M, Vinodhana NK, Sumathi $P$, 2013. Hierarchical clustering of pearl millet (Pennisetum glaucum (L.) R. Br) in breeds for morphophysiological traits. Int J Curr Microbiol Appl Sci, 2(12): 647-652.

Tabo R, 1995. Performances of sorghum and millet varieties under varying combinations of animal manures and chemical fertilizer. pp 53-54. In: ICRISAT and Collaborative Programmes. West and Central Africa Annual Report.

Tajul MI, Alam MM, Hossain SMM, Naher K, Rafii MY, Latif MA, 2013. Influence of plant population and nitrogen-fertilizer at various levels on growth and growth efficiency of maize. Sci World J, 2013: 193018.

Taylor JRN, 2004. Pearl millet. University of Pretoria, Pretoria, South Africa. 132p.

Uzoma AO, Eze PC, Alabi M, Mgbonu K, Aboje JE, Osunde AO, 2010. The effect of variety and planting date on the growth and yield of pearl millet in southern guinea savanna zone of Nigeria. J Agric Vet Sci, 2: 122-129.

Wilson JP, Hanna WW, Gascho G, Wilson GM, 1995. Pearl millet grain loss from rust infection. In: Proceedings of the First National Grain Pearl Millet Symposium, 17-18 Jan (Teare ID. ed.) Tifton, Georgia, USA: University of Georgia and USDA; 54-56.

Yadav OP, 2010. Drought response of pearl millet landrace-based populations and their crosses with elite composites. J Field Crops Res, 118: 51-56.

Citation: Ajeigbe HA, Akinseye FM, Kunihya A, Abdullahi Al, Kamara $A Y, 2019$. Response of pearl millet (Pennisetum glaucum, L.) to plant population in the semi-arid environments of Nigeria. Net J Agric Sci, 7(1): 13-22. 